\title{
Plýtvání potravinami ve školních jídelnách
}

\section{Zdeněk Talácko}

Envigogika 15 (1) - I nspirace/ I nspirations

Publikováno / Published 28. 09. 2020

DOI: $10.14712 / 18023061.604$

\begin{abstract}
Abstrakt
Moderní doba nese s sebou ruku $v$ ruce dostatek prakticky všeho. Máme všeho takový přebytek, že i využití potravin beze zbytku je prakticky nemožné; také úprava a príprava pokrmů je stále rychlejší. Tento článek se zabývá plýtváním ve školních jídelnách. Jsou to hlavně děti, které ve školách bez dostatečné kontroly rodičů a učitelů jídlem plýtvají. Je však na každém z nás, jakým způsobem budeme ke stravování přistupovat - můžeme se vzdělávat a zajímat se o danou problematiku. Zároveň musíme obecně povědomí o škodlivosti plýtvání a nevyužívání zdrojů šiřit dále. Pokud se bude dařit tuto věkovou kategorii vzdělávat a učit, jak s potravinami nakládat, můžeme do budoucna zlepšit i celkovou situaci s využíváním potravin.
\end{abstract}

\section{Klíčová slova}

Vzdělání; spotřeba potravin; plýtvání; školní jídelny

\begin{abstract}
There is enough of virtually everything in modern times. This concerns also food; also the preparation of food is getting faster - not wasting is virtually impossible also in this sector. The article deals with waste in school canteens. It is mainly children who-without sufficient control of their parents and teachers -waste food in schools. However, it is up to each of us how we approach eating - we can educate ourselves and be interested in the issue. At the same time, we need to spread the awareness of the harmfulness of wasting resources in general. If we succeed in educating school children and teach them how to deal with food, we can improve the overall food use situation in the future.
\end{abstract}

\section{Keywords}

Education; food consumption; waste; school canteens 


\section{Máme všeho dostatek}

Moderní doba nese s sebou ruku v ruce dostatek prakticky všeho. Vývoj nových technologií jde kupředu velkým tempem a platí to i v potravinářském průmyslu. Stálé vylepšování nových strojů a kuchyňských spotřebičů vstupuje do domácností, restauračních zařízení a $v$ neposlední řadě do velkých vývařoven a školních jídelen. A stejně jako nás výkonnější motory u aut dokážou přesunout $z$ bodu $A$ do bodu $B$ rychleji, je jasně rychlejší $i$ úprava a př́prava potravin. To přináší jak pozitiva, tak i negativa. Bohužel však množství zpracovaných potravin je zbytečně nadměrné, a tak snadno dochází k jeho nedostatečné konzumaci a tudíz plýtvání. Zařízení, kde se toto děje, je velké množství. Podívejme se napríklad na školní jídelny. Jsou to právě děti, které ve školách bez dostatečné kontroly (rodičů, učitelů ad.) jídlem plýtvají. Jako jeden z hlavních faktorů, které s tímto problémem souvisí, jsou mobilní telefony. Toto zařízení ovlivňuje náš stravovací režim víc, než si vůbec uvědomujeme. A děti jsou v naprostém centru tohoto dění. Je běžné, že po usednutí ke stolu, místo toho, aby uchopily př́bor, jako první věc udělají to, že vezmou mobil do ruky. A tam vše začíná. Koncentrace a klid, který by měl u jídla být, nepřichází. Roztěkanost a nesoustředěnost na samotné stravování způsobí, že dítě o jídlo vlastně nejeví zájem, protože středem jeho pozornosti je $v$ onu chvíli mobilní telefon. Jídlo na talíri mezitím vystydne, stane se pro dítě „nepoživatelným", a tak si dítě snadno řekne, že studený knedlík s masem přeci nebude jíst. Nedojedené jídlo odnáší, a to končí většinou nevyužité v odpadcích. Zároveň se prodlužuje i doba strávená u jídla. Opět právě kvưli mobilnímu telefonu.

Pokusíme se nyní v číslech shrnout fakta, která poukazují na současnou situaci, a představit řadu organizací, spolků a projektů, které se snaží tuto problematiku řešit.

\section{Fakta, čísla, grafy}

Deník.cz v srpnu roku 2019 přišel se zajímavým grafickým znázorněním hlavních čísel, která se týkají právě školních jídelen ${ }^{1}$. Myslím si, že čísla jsou všeříkající.

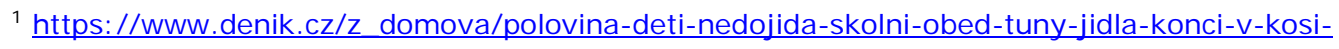
20190830.html 
Jenom si představme tu obrovskou sumu 2,5 miliardy korun, která skončí v odpadcích. Jsou to peníze, které ročně odchází $z$ peněženky rodičů za jídlo, které je vyhozeno. Množství tohoto jídla je pak téměř 150 tun každý den. Samotná představa tohoto množství jídla i peněz je zarážející.

Dalším faktem je to, že $z$ celkově připravených jídel se vyhodí $20-35 \%{ }^{2}$. Konkrétní príklady uvádí brožura vydaná $v$ rámci projektu Menu pro změnu: "na světě se vyplýtvá nebo jinak přijde nazmar až třetina potravin. Spotřebitelé $v$ průmyslových zemích vyplýtvají ročně tolik potravin (222 milionů tun), kolik se jich vyprodukuje $v$ celé subsaharské Africe ( 230 milionů tun). Předpokládá se, že $v$ Evropské unii přijde ročně vniveč až 89 milionů tun potravin. Abychom byli konkrétnější: to je, jako by každý člověk týdně vyhodil čtyři celé pokrmy." 3

\section{Projekty, organizace, spolky}

$\checkmark$ posledních letech se stále více organizací a spolků začíná zajímat o tuto problematiku. Vznikají různé varianty a nápady, jak vytvořit ve školství větší povědomí o realitě, kterou všichni žijeme. Jsou to právě děti, které jsou hlavními hybateli v této problematice, a proto je správné, že cíleně pro tuto věkovou kategorii vznikají vzdělávací projekty, které se snaží co nejvíce dané problémy vysvětlit a zároveň nabízet řešení, jak Ize dojít ke změnám.

J edním z nich je i Mezinárodní projekt "Menu pro změnu", který se do českých škol a školek dostává díky programu Ekoškola. „Celý projekt obsahuje řadu témat, která se vážou k zodpovědné spotřebě potravin, např́klad zařazování sezónních a místních potravin; děti se dozvědí, co jsou fair-trade potraviny, palmový olej, plýtvání, nadměrné používání průmyslově zpracovaných potravin." ${ }^{4}$ Díky zajímavé publikaci ${ }^{5}$ nabízí tento program otázky a odpovědi v globálním měřitku. Vše zastřešuje společnost Glopolis o.p.s.. To „je od roku 2004 nezávislé centrum pro analýzy a sítování na podporu odolné občanské společnosti, udržitelné

\footnotetext{
${ }^{2}$ Online dostupné zde.

${ }^{3}$ https://www.eatresponsibly.eu/cs/

${ }^{4}$ https://www.jidelny.cz/show.aspx?id=1841

${ }^{5}$ Online dostupné zde.
}

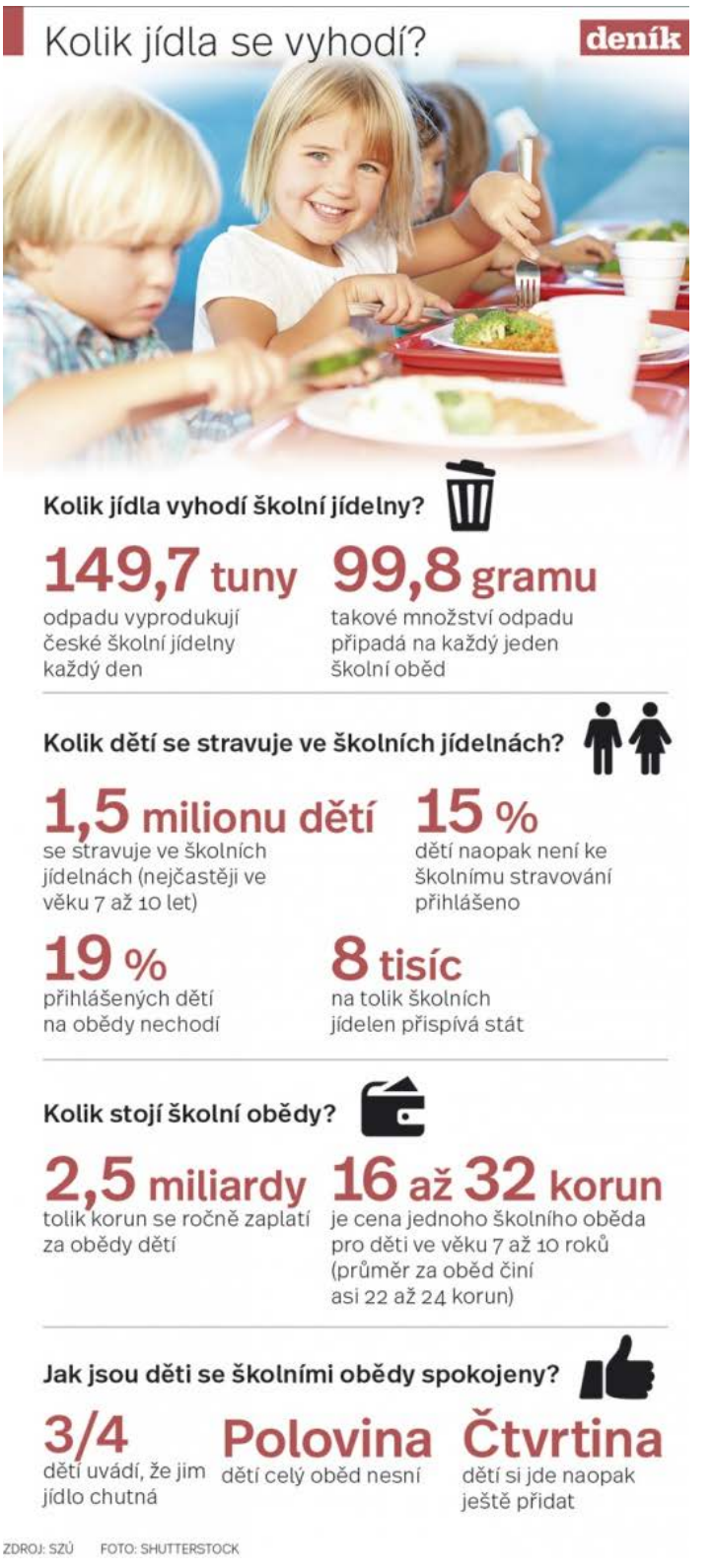


ekonomiky a odpovědné demokracie napříč společenskými bublinami.“ Partnerem projektu je iTEREZA, vzdělávací centrum ${ }^{6}$.

Dalším projektem, který tato společnost realizuje, je "Neplýtváme tím, co jíme“. Ten je zapojen do mezinárodního programu STREFOVA (strategies to reduce food waste). Mezi hlavní myšlenky, na které se snaží poukazovat, patří především globální plýtvání nejen potravinami, ale i dalšími zdroji, potřebnými pro jejich pěstování, produkci, zpracování a $v$ neposlední řadě i likvidaci. „Nehospodárné zacházení s jídlem přitom představuje nemalou ekonomickou a ekologickou zátěž. Prírodní zdroje vložené do produkce potravin, které se nevyužijí, přicházejí vniveč. Vyhozené jídlo se nadto musí přepravit na skládky a následně zlikvidovat. K finančním ztrátám dochází na globální úrovni, ale i v domácnostech, které nakupují více, než jsou schopny samy spotřebovat." 7

Co je však velmi důležité, je vzájemná spolupráce s českými základními školami a školkami a Potravinovou bankou Praha. Projekt "Neplýtváme tím, co jíme“ se v druhé polovině roku 2018 zaměřil na spolupráci s 12 školami po celé České republice. "Z počátku školního roku se zástupcům z řad učitelů nabídlo 6 tematicky laděných lekcí, variované pro 1 . i 2. stupeň. Také jim byla představena základní př́ručka $\mathrm{k}$ tématu, aby měli $\mathrm{k}$ realizaci lekce co nejsnazší cestu. $V$ těchto školách pak docházelo $k$ testování, jak dané lekce fungují $v$ realitě školních hodin. Vyžádaná zpětná vazba pak byla zapracována a vedla $\mathrm{k}$ vytvoření kompletní sady lekcí, které jsou k dispozici veřejnosti na webových stránkách projektu. Více v přiloženém odkazu: http://www.reducefoodwaste.eu/.

Další iniciativu ve směru vzdělávání a vytváření povědomí o situaci potravin ve školství vytvárí spolek "Skutečně zdravá škola". Školy zapojené do spolupráce s tímto projektem „pomáhají dětem získat představu o tom, odkud jídlo pochází a jak se pěstuje nebo vyrábí. Umožňuji svým žákům porozumět vztahům mezi jídlem, které jí, a světem, ve kterém žijí. Děti si ze školy odnášejí základy zdravých stravovacích návyků a znalosti, dovednosti, postoje a kompetence nutné pro udržitelný život. “ 8

Velice dobře zpracovaný program nabízí informace pro všechny, kteří mohou být aktivně zapojeni. Tedy, vedení školy, učitelé, kuchařky a vedení jídelny a $v$ neposlední řadě $i$ aktivní rodiče. Pro vedení školy nacházíme informace, jak Ize do projektu vstoupit, jaká jsou kritéria a jaké vzdělávání $v$ tomto směru Ize nabídnout dalším lidem. Učitelé mohou nalézt širokou škálu metodických materiálů k různým bodům této problematiky, odkazy na kampaně a projekty. Lze se dočíst spoustu informací z praxe a zároveň se školy mohou zapojit do spolupráce s vybranými farmami, které samotné aktivity v praxi nabízejí.

Kuchařkám a vedení školních jídelen je k dispozici online kuchařka, která nabízí až 115 různých jídel. Od pomazánek, salátů a polévek, přes masová i bezmasá jídla, až po rybí pokrmy a sladká jídla. Velmi užitečné jsou také informace týkající se chemických aditiv („éček"); doporučení jak a kde nakupovat kvalitní potraviny od místních dodavatelů, připadně jak Ize využívat vlastní vypěstované potraviny, to vše v souladu s vyjádřením Ministerstva zdravotnictví ${ }^{9} . \vee$ neposlední řadě projekt nabízi informace pro rodiče - jak a proč se mohou zapojit. Vždyt́ právě oni jsou zdrojem peněz, které končí doslova utopeny v kontejnerech...

\footnotetext{
${ }^{6}$ https://glopolis.org/o-glopolis/, http://terezanet.cz/

${ }^{7}$ https://www. interreg-central.eu/Content. Node/STREFOWA.html

${ }^{8}$ http://www. skutecnezdravaskola.cz/o-nas

9 http://www.skutecnezdravaskola.cz/navody-a-tipy
} 


\section{Jaké další možnosti máme?}

Ve školství je situace pro možné recyklování zbylých potravin náročná. Prostorově to ne vždy Ize, zvlášt' je-li škola někde uprostřed města. Venkovské školy mají oproti tomu velkou výhodu, at' už z hlediska prostor, ale také z hlediska dostupnosti zdrojů, resp. možností jak nevyužité či již upravené potraviny zpracovávat a likvidovat.

Domnívám se však, že má-li se změnit k lepšímu situace ve školství, kde naše děti jídla vracejí, musí se také zlepšit situace v domácnostech, kde děti vyrůstají a získávají základní stravovací návyky.

Zajímavá řešení nabízí rakousko-český projekt FUWA (future of waste), který „řeší postupy, jak zkvalitnit způsoby nakládání s odpady, podporuje výměnu přeshraničních zkušeností a umožňuje vypracování konceptů a hledání nových řešení na všech stupních likvidace odpadu, zejména pro struktury osídlení v malých obcích v příhraničních regionech." 10

Brožura o 17 stránkách, která je zaměřena na správné nakládání s potravinami v domácnostech, přináší několik nápadů, jak předcházet plýtvání.

Vše začíná dobrým plánováním stravování a samotného nákupu. Zamyšlení nad tím, zda opravdu potřebuji to či ono a zda nepodléhám pouze slevovým nabídkám, dobře vypadajícím produktům, či chutím a hladu, je základem. Důležité následně je, abychom potraviny správně uskladňovali. Zachování jejich nejdelší trvanlivosti nám pomůže je systematicky využívat, at' už se jedná o ovoce a zeleninu, pečivo, či balené potraviny, maso, konzervy a další. Dostaneme-li se do fáze, že objevíme něco, co jsme delší dobu nevyužili, je nezbytné správně rozlišit dvě data, která mohou být na etiketě výrobku. Datum minimální trvanlivosti a datum spotřeby. Tyto údaje musíme brát na zřetel, abychom náhodou nevyhazovali jídlo, kterému nic není. Samotné vaření je pak spojeno s přiměřenými porcemi a rozumným množstvím využitých potravin. Zbyde-li nám jídlo, je spousta variant, jak je lze konzervovat či okamžitě přetvořit v jiný pokrm, který pro nás získá nový smys| ${ }^{11}$. Vše je spojeno s rozumným rozmýšlením od samotného nákupu až po poslední možné využití. Občas to chce jen trochu fantazie.

\section{Závěrem}

Domnívám se, že plýtvání potravinami se v dnešní době nelze zcela vyhnout. Bohužel máme všeho takový přebytek, že využití potravin naprosto beze zbytku je prakticky nemožné. Nicméně je na každém z nás, jakým způsobem budeme ke stravování přistupovat. Jako v každém oboru není složité se vzdělávat a zajímat se o danou problematiku. Zároveň musíme obecně povědomí o škodlivosti plýtvání a nevyužívání zdrojư šiřit dále. Jak jsem již zmiňoval, jak v rodinách, tak ve školství, jsou hlavním faktorem děti. Pokud se nám bude dařit právě tuto věkovou kategorii vzdělávat a učit, jak s potravinami nakládat, myslím, že můžeme do budoucna zlepšit i celkovou situaci s využíváním potravin.

\footnotetext{
${ }^{10}$ http://futureofwaste.eu/cs/o-projektu-future-of-waste

${ }_{11} \mathrm{http}$ ://futureofwaste.eu/public/download/Nvod_jak_pedchzet_vyhazovn_potravin_v_domcnostech.pdf
} 


\section{Zdroje, seznam literatury}

- $\quad$ https://www.denik.cz/z_domova/polovina-deti-nedojida-skolni-obed-tuny-jidlakonci-v-kosi-20190830. html

- $\quad$ https: //www.jidelny.cz/show.aspx?id=1841

- $\quad$ https://s3.eu-central-1.amazonaws.com/uploads.mangoweb.org/sharedprod/eatresponsibly.eu/uploads/2016/11/MenuProZmenu_brozuraCZ_FINAL_NAHLED.pdf

- $\quad$ https://glopolis.org/glopolis/o-nas

- $\quad$ https://glopolis.org/_project/strefowa

- $\quad$ http://www.skutecnezdravaskola.cz/o-nas

- https://www.novinky.cz/veda-skoly/clanek/ve-skolnich-jidelnach-se-kazdorocnevyhodi-az-48-tisic-tun-potravin-kritizuje-iniciativa-40060852

- http://glopolis.org/wp-content/uploads/TZ_de\% CC\% 8Cti-aktivni\% CC\% 81-hybatele\% CC\% 81.pdf

- http: //futureofwaste.eu/cs/o-projektu-future- of-waste

- http://futureofwaste.eu/public/download/Nvod_jak_pedchzet_vyhazovn_potravin_v_domcnostech.pdf

- https://www.denik.cz/z_domova/polovina-deti-nedojida-skolni-obed-tuny-jidlakonci-v-kosi-20190830.html 